\title{
Effects of seeding dates on dry matter yield and feed values of whole-crop barley cultivated in a paddy field
}

\author{
Sang Moo Lee and Eun Joong Kim * \\ Department of Animal Science, Kyungpook National University, Sangju 37224, Korea
}

\begin{abstract}
This study was carried out to investigate the effects of seeding dates on the yield and feed value of whole-crop barley cultivated in paddy soil. The field experiment was conceived as a randomized block design performed in triplicate with seeding dates of Oct. 19 (T1 as treatment 1), Oct. 26 (T2 as treatment 2), Nov. 2 (T3 as treatment 3), Nov. 9 (T4 as treatment 4), and Nov. 16 (T5 as treatment 5) as treatments. The barley grown in all treatments was harvested on May 21 of the following year. Plant length, fresh yield, dry matter yield, and total digestible nutrient (TDN) yield were higher $(p<0.05)$ in barley with early seeding dates, whereas crude protein and ether extract were higher $(p<0.05)$ with late seeding dates. Crude fiber and neutral detergent fiber were highest in the T3 treatment and lowest in the T1 treatment. There was no significant difference between acid detergent fiber and TDN among the different seeding dates. Total mineral contents were higher in the order T1 $>\mathrm{T} 2>\mathrm{T} 3>\mathrm{T} 4>\mathrm{T} 5(p<0.05)$, whereas the total amino acid content increased significantly $(p<0.05)$ with a delay in seeding date. Free sugar contents (fructose, glucose, and sucrose) were higher with early seeding dates $(p<0.05)$. Collectively, the results obtained in this study indicate that it is favorable to seed soon after harvesting rice to increase dry matter and TDN yields and mineral and free sugar contents of whole-crop barley in the midlands of Korea.
\end{abstract}

Keywords: Whole-crop barley, Seeding dates, Dry matter yield, Total digestible nutrients

\section{Background}

With the continuing steep increase in the number of ruminant animals, mainly beef cattle, reared on farms, there has been a concomitant increase in the demand for forage and concentrate. However, in Korea, because there is a limited production capacity for forage and grains, dependency on foreign imports has been rising. The price of imported hay and grain can fluctuate markedly, depending on international supply capacity, and under such circumstances it is difficult for farmers to continue rearing livestock [1]. Therefore, to supply home-produced meat to customers in Korea, it is imperative to expand forage production capability to meet the demand for ruminant production. In a country like Korea with limited agricultural land area, using agricultural land that remains idle after rice crop cultivation accordingly represents a very important approach for increasing forage production [2].

A forage crop suitable for this purpose is whole-crop barley, which has strong moisture tolerance when grown in paddy fields [3], a high feed value [4], and high quality silage, which makes it suitable as a winter crop [5]. In addition, whole-crop barley can improve feed efficiency and meat quality, and reduce feed costs compared with rice straw [6,7]. There are several reports available in the literature describing new varieties of whole-crop barley that are adaptable to Korean agricultural land [8-10], and good in 
terms of dry matter yield and nutritive value [4,7,11], and seeding method and rate [12]. However, to date, there have been no reported studies on the mineral contents, amino acid compositions, and free sugar contents of these varieties. Therefore, this study was conducted to investigate the effects of different seeding dates on the dry matter yield, total digestible nutrients (TDN), and compositions of minerals, amino acids, and free sugars when forage barley was seeded in a paddy field after harvesting a rice crop. The results of this study will provide livestock producers and/or forage makers with fundamental information on appropriate seeding dates for cultivation of winter barley in paddy fields.

\section{Materials and Methods}

\section{Experimental design, seeding, and forage yield}

This field experiment was performed from October 19, 2009 to May 21, 2010 in a paddy field in the northwestern region of Gyeongbuk Province (latitude 36.5592, longitude 128.1885), Korea. The field experiment employed a randomized complete block design with five different seeding dates as experimental treatments: Oct. 19 (T1 as treatment 1), Oct. 26 (T2 as treatment 2), Nov. 2 (T3 as treatment 3), Nov. 9 (T4 as treatment 4), and Nov. 16 (T5 as treatment 5). The barley grown in all treatments was harvested on May 21 of the following year. The whole-crop barley cultivar used for the experiment was "Yuyeon," which was developed in Korea [13]. The paddy field used for the field experiment had higher organic matter and nitrogen content and lower phosphate content than a general upland soil, as previously reported by Lee [14]. The application rates of chemical fertilizer were as follows: total nitrogen (200 $\mathrm{kg} / \mathrm{ha})$, phosphorus $(150 \mathrm{~kg} / \mathrm{ha})$, and potassium $(150 \mathrm{~kg} / \mathrm{ha})$. The chemical fertilizer was applied with $40 \%$ nitrogen and potassium used as a basal fertilizer and $60 \%$ as added fertilizer, whereas total phosphorus was applied as a basal fertilizer. As a seeding method, the whole-crop barley was broadcasted on the soil at a rate of 180 $\mathrm{kg} / \mathrm{ha}$. The experimental plot area was $3 \mathrm{~m} \times 5 \mathrm{~m}=15 \mathrm{~m}^{2}$. Fresh forage yield was estimated after cutting $5 \mathrm{~m}^{2}$ in each replicate.

\section{Analysis of chemical composition}

The samples were dried for 3 days at $55^{\circ} \mathrm{C}$ and used for analysis. The chemical composition of the samples was determined by using the method specified by the Association of Analytical Chemists (AOAC) [15]. Acid detergent fiber (ADF) and neutral detergent fiber (NDF) were analyzed using the methods of AOAC [16] and, the Goering and Van Soest method [17], respectively. The TDN was estimated using the equation of Moore and Undersander [18]: $\mathrm{TDN}=88.9-(0.79 \times \mathrm{ADF})$. The mineral composition was analyzed from pre-treated samples using inductively coupled plasma mass spectrometry (Iris Intrepid, Thermo Elemental Co., UK).
Analysis of the amino acid profile was performed in the following sequence. To $1 \mathrm{~g}$ of accurately weighed pulverized sample in a test tube, $10 \mathrm{~mL}$ of $6 \mathrm{~N} \mathrm{HCl}$ was added. Following a reduction in pressure, the tube was sealed and the sample was then subjected to hydrolysis at $110^{\circ} \mathrm{C}$ in a drying oven for $24 \mathrm{~h}$. The pre-treated sample was then filtered through a $0.45-\mu \mathrm{m}$ membrane filter, and the filtered sample was analyzed using an automatic amino acid analyzer (Biochrom 30, Biochrom Ltd, Cambridge, England). Free sugar was analyzed using the method of Wilson et al. [19]. Briefly, $100 \mathrm{~mL}$ of $80 \%$ ethanol solution was added to $5 \mathrm{~g}$ of sample. The sugar composition was then extracted repetitively for $2 \mathrm{~h}$ at $80^{\circ} \mathrm{C}$ using the heating mantle in a reflux cooling extraction unit followed by filtering through Whatman No. 5 filter paper. The resulting solution was then analyzed using high-performance liquid chromatography (Waters 2414, Waters Co., USA).

\section{Statistical analysis}

The results were subjected to one-way analysis of variance with seeding date as a main effect. Mean values and standard deviations of the experimental results were obtained using SAS [20]. Duncan's multiple range test was employed to identify differences among the treatments, which were considered significant when $p<$ 0.05 .

\section{Results and Discussion}

\section{Growth characteristics and dry matter yield}

The growth characteristics according to seeding date are shown in Table 1. Plant length varied in the following order $\mathrm{T} 1>\mathrm{T} 2>\mathrm{T} 3>$ $\mathrm{T} 4>\mathrm{T} 5(p<0.05)$. Consistent with the findings of Kim et al. [12], it was shown that the plant length of whole-crop barley became shorter with an increasing delay in seeding date. Stem diameter increased significantly until the grain was formed (i.e., T5 $<\mathrm{T} 4<$ T3); however, it decreased with maturation of the grain (T3 > T2 $>$ T1). Fresh and dry matter yields were higher when the seeding date was earlier $(p<0.05)$, and there was a notable trend of rapidly decreasing yield with the progression of November seeding dates (T3, T4, and T5). The results of this study are in line with those reported by Kim et al. [2] and Suh [21], who demonstrated that when cultivating winter crops after rice cultivation, there was a difference in yield according to the seeding date. Kim et al. [2] reported that when seeding date is delayed in autumn, the average temperature drops and average winter survival rates rapidly decrease, resulting in a reduced dry matter yield. In the present study, it was shown that TDN yield was significantly higher $(p<0.05)$ in $\mathrm{T} 1$ than in the other treatments, particularly $\mathrm{T} 3, \mathrm{~T} 4$, and $\mathrm{T} 5$, with late seeding dates being associated with a very low yield $(p<0.05)$. These results are consistent with those reported by Kim et al. [2], 
Table 1. Effect of seeding dates on the growth characteristics and yield of whole-crop barley cultivated in a paddy field

\begin{tabular}{|c|c|c|c|c|c|}
\hline \multirow{2}{*}{ Items } & \multicolumn{5}{|c|}{ Treatments $^{1)}$} \\
\hline & T1 & T2 & T3 & T4 & T5 \\
\hline Plant length $(\mathrm{cm})$ & $101.4 \pm 2.5^{\mathrm{a}}$ & $96.2 \pm 3.1^{b}$ & $94.6 \pm 2.1^{b}$ & $87.8 \pm 3.1^{c}$ & $80.6 \pm 1.7^{\mathrm{d}}$ \\
\hline Stem diameter $(\mathrm{mm})$ & $5.5 \pm 0.2^{\mathrm{bc}}$ & $5.9 \pm 0.1^{a}$ & $6.0 \pm 0.2^{\mathrm{a}}$ & $5.7 \pm 0.3^{\mathrm{ab}}$ & $5.2 \pm 0.2^{c}$ \\
\hline Fresh yield (kg/ha) & $50,514 \pm 1,112^{\mathrm{a}}$ & $32,700 \pm 2,321^{b}$ & $25,426 \pm 2,807^{c}$ & $20,792 \pm 1,446^{d}$ & $8,729 \pm 1,558^{\mathrm{e}}$ \\
\hline Dry matter yield (kg/ha) & $9,952 \pm 218^{a}$ & $7,390 \pm 524^{b}$ & $5,594 \pm 459^{c}$ & $4,636 \pm 322^{d}$ & $1,947 \pm 347^{e}$ \\
\hline TDN yield(kg/ha) & $5,987 \pm 130^{\mathrm{a}}$ & $4,399 \pm 312^{b}$ & $3,328 \pm 273^{c}$ & $2,754 \pm 192^{d}$ & $1,148 \pm 205^{\mathrm{e}}$ \\
\hline
\end{tabular}

Data are expressed as means \pm SD.

Means in a row with different superscripts are significantly different $(p<0.05)$.

${ }^{11} \mathrm{~T} 1, \mathrm{~T} 2, \mathrm{~T} 3, \mathrm{~T} 4$, and T5 represent the different seeding dates: October 19 , October 26 , November 2, November 9 , and November 16 , respectively.

TDN, total digestible nutrients, yield $=[88.9-(0.79 \times$ acid detergent fiber $(\%))] \times$ dry matter yield $/ \mathrm{ha}$.

who showed that TDN and dry matter yield increased with earlier seeding dates in winter crops. Therefore, to increase the yield of whole-crop barley in the Korean midlands after rice cultivation, it is favorable to seed soon after the rice has been harvested.

\section{Chemical composition}

The chemical composition of whole-crop barley according to seeding date is presented in Table 2 . The crude protein and ether extract contents of whole-crop barley decreased significantly with an earlier seeding date $(p<0.05)$, whereas crude ash content increased with an earlier seeding date $(p<0.05)$. NDF increased until the time of grain formation time; however, it decreased during the grain maturity stage $(p<0.05)$. This is presumably because as the cultivation period increases, maturity stages develop, the leaf ratio of the plant decreases, and stems harden [2,22]. There was no significant difference between the ADF and TDN content in relation to seeding date. The chemical compositions of forage crops differ significantly, depending on cutting time [23], maturity stage [24], variety [2], seeding date [2], and manure conditions [25]. In the present study, feed value appeared to be high in the late seeding groups (T4 and T5); however, as shown in Table 4, when the seeding date is late, there is a significant decrease in yield. Therefore, seeding dates should be determined by taking into consideration the requisite dry matter yield and nutritional value.

\section{Mineral contents}

The mineral contents of whole-crop barley according to seeding date is presented in Table 3. Irrespective of seeding date, the mineral contents of whole-crop barley were higher in the order $\mathrm{K}$ > $\mathrm{Ca}>\mathrm{Na}>\mathrm{Mg}$. A similar trend has been reported by Lee [25] and Lee [14]. The $\mathrm{Ca}, \mathrm{K}$, and $\mathrm{Na}$ contents were highest in $\mathrm{T} 1(p<0.05)$, whereas $\mathrm{Fe}$ content was highest in $\mathrm{T} 2$ and $\mathrm{P}$ content was highest in T4 $(p<0.05)$. Total mineral content was highest for seeding date T1 $(p<0.05)$ at $31,308 \mathrm{mg} / \mathrm{kg}$ and lowest for T5 $(p<0.05)$ at $15,978 \mathrm{mg} / \mathrm{kg}$. These values are lower than those reported by Kim and Lee [1], who determined mineral contents of between 39,027 and $51,914 \mathrm{mg} / \mathrm{kg}$ for whole-crop barley varieties. Generally, it is known that mineral content is affected by a range of conditions,

Table 2. Effects of seeding dates on the chemical composition of whole-crop barley cultivated in a paddy field (\% of dry matter basis unless otherwise stated)

\begin{tabular}{|c|c|c|c|c|c|}
\hline \multirow{2}{*}{ Items } & \multicolumn{5}{|c|}{ Treatments $^{1)}$} \\
\hline & T1 & T2 & T3 & T4 & T5 \\
\hline Crude protein & $12.2 \pm 0.2^{c}$ & $12.7 \pm 0.1^{c}$ & $13.5 \pm 0.1^{b}$ & $13.8 \pm 0.2^{b}$ & $15.4 \pm 0.6^{a}$ \\
\hline Ether extract & $1.8 \pm 0.1^{b}$ & $1.9 \pm 0.1^{b}$ & $1.9 \pm 0.0^{b}$ & $2.1 \pm 0.0^{\mathrm{a}}$ & $2.1 \pm 0.1^{a}$ \\
\hline Crude ash & $9.7 \pm 0.1^{\mathrm{a}}$ & $9.1 \pm 0.1^{b}$ & $8.9 \pm 0.1^{b c}$ & $9.0 \pm 0.1^{b c}$ & $8.8 \pm 0.1^{c}$ \\
\hline Crude fiber & $28.5 \pm 0.4^{b}$ & $30.9 \pm 0.2^{\mathrm{a}}$ & $31.1 \pm 0.7^{\mathrm{a}}$ & $30.5 \pm 0.3^{\mathrm{a}}$ & $30.9 \pm 1.3^{\mathrm{a}}$ \\
\hline NDF & $58.6 \pm 0.3^{b}$ & $59.9 \pm 0.2^{\mathrm{a}}$ & $61.8 \pm 0.5^{\mathrm{a}}$ & $60.5 \pm 0.7^{a}$ & $60.2 \pm 0.7^{\mathrm{a}}$ \\
\hline ADF & $36.9 \pm 1.2^{\text {ns }}$ & $37.5 \pm 0.8$ & $37.2 \pm 2.6$ & $37.3 \pm 1.5$ & $37.7 \pm 0.9$ \\
\hline TDN & $60.0 \pm 1.0^{\text {ns }}$ & $59.5 \pm 0.3$ & $59.3 \pm 2.1$ & $59.4 \pm 1.2$ & $59.0 \pm 0.7$ \\
\hline
\end{tabular}

Data are expressed as means \pm SD.

Means in a row with different superscripts are significantly different $(p<0.05)$.

${ }^{11} \mathrm{~T} 1, \mathrm{~T} 2, \mathrm{~T} 3, \mathrm{~T} 4$, and T5 represent the different seeding dates: October 19, October 26, November 2, November 9, and November 16, respectively.

NDF, neutral detergent fiber; ADF, acid detergent fiber; TDN, total digestible nutrients [88.9- $(0.79 \times$ acid detergent fiber $(\%))]$; ns, not significant. 
Table 3. Effects of seeding dates on the mineral contents of whole-crop barley cultivated in a paddy field (mg/kg dry matter basis unless otherwise stated)

\begin{tabular}{|c|c|c|c|c|c|}
\hline \multirow{2}{*}{ Items } & \multicolumn{5}{|c|}{ Treatments ${ }^{1)}$} \\
\hline & T1 & T2 & T3 & T4 & T5 \\
\hline $\mathrm{Ca}$ & $10,102 \pm 242^{a}$ & $10,722 \pm 360^{a}$ & $9,260 \pm 203^{b}$ & $5,626 \pm 63^{c}$ & $4,992 \pm 180^{d}$ \\
\hline $\mathrm{Cu}$ & $4 \pm 0^{a}$ & $4 \pm 0^{a}$ & $4 \pm 0^{a}$ & $3 \pm 0^{b}$ & $3 \pm 0^{b}$ \\
\hline $\mathrm{Fe}$ & $348 \pm 7^{b}$ & $427 \pm 25^{\mathrm{a}}$ & $352 \pm 13^{b}$ & $198 \pm 15^{c}$ & $182 \pm 14^{c}$ \\
\hline $\mathrm{K}$ & $18,568 \pm 361^{\mathrm{a}}$ & $15,015 \pm 946^{b}$ & $9,461 \pm 1,177^{c}$ & $9,434 \pm 542^{c}$ & $9,561 \pm 621^{\mathrm{c}}$ \\
\hline $\mathrm{Mg}$ & $479 \pm 23^{b}$ & $679 \pm 9^{a}$ & $754 \pm 44^{\mathrm{a}}$ & $526 \pm 32^{b}$ & $374 \pm 71^{\mathrm{c}}$ \\
\hline $\mathrm{Mn}$ & $26 \pm 1^{b}$ & $29 \pm 2^{\mathrm{a}}$ & $25 \pm 2^{b}$ & $19 \pm 2^{c}$ & $21 \pm 2^{c}$ \\
\hline $\mathrm{Na}$ & $1,370 \pm 103^{\mathrm{a}}$ & $822 \pm 21^{b}$ & $747 \pm 21^{b}$ & $459 \pm 7^{c}$ & $256 \pm 13^{d}$ \\
\hline $\mathrm{Zn}$ & $18 \pm 3^{c}$ & $23 \pm 2^{\mathrm{a}}$ & $23 \pm 1^{\mathrm{ab}}$ & $20 \pm 2^{b c}$ & $18 \pm 1^{c}$ \\
\hline $\mathrm{P}$ & $392 \pm 38^{c}$ & $371 \pm 15^{c}$ & $408 \pm 30^{c}$ & $648 \pm 21^{a}$ & $571 \pm 37^{b}$ \\
\hline 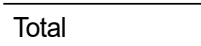 & $31,308 \pm 501^{a}$ & $28,093 \pm 1,206^{b}$ & $21,033 \pm 1,028^{c}$ & $16,934 \pm 501^{d}$ & $15,978 \pm 582^{d}$ \\
\hline
\end{tabular}

Data are expressed as means \pm SD

Means in a row with different superscripts are significantly different $(p<0.05)$.

${ }^{1)} \mathrm{T} 1, \mathrm{~T} 2, \mathrm{~T} 3, \mathrm{~T} 4$, and T5 represent the different seeding dates: October 19, October 26, November 2, November 9 and November 16, respectively.

including those of weather, soil, and fertilization [26-28].

Interestingly, information on the mineral contents of wholecrop barley cultivars and other domestically produced forages (i.e., fresh or conserved Italian ryegrass) that have been developed in Korea is extremely limited in the literature, and consequently it is difficult to compare our results with published data. There may be several reasons for the lack of information regarding mineral contents. Firstly, this is presumably attributable to the difficulty in performing the analytical procedures necessary to assess individual mineral contents, as they are expensive and laborious compared with those of the simple proximate analyses commonly performed in feed analytical laboratories [29]. Secondly, the quantity of domestically produced fresh or conserved forages as a forage source to supply nutrients to ruminants has traditionally been limited, and therefore the mineral contents of these forages have seldom been considered as a significant ingredient when formulating diets for ruminants. However, this latter possibility may no longer pertain because forage production within Korea has been encouraged by the central government, and production has been steeply increasing over the last few years [2]. Therefore, for farmers and feed formulators, as well as for consultants, information such as the mineral contents of domestically produced feed resources will become immensely important.

\section{Amino acids profile}

The amino acid compositions of whole-crop barley according to seeding date are presented in Table 4. In terms of essential amino acids, there was no difference among treatments. The total essential amino acid content showed a trend of $\mathrm{T} 4>\mathrm{T} 3>\mathrm{T} 5>\mathrm{T} 2>\mathrm{T} 1$, although no significant difference was noted. For non-essential amino acids, all treatment groups had high glutamic acid, proline, and aspartic acid contents. The non-essential amino acid content trend was $\mathrm{T} 5>\mathrm{T} 4>\mathrm{T} 3>\mathrm{T} 2>\mathrm{T} 1(p<0.05)$. The range of total amino acids by seeding date was from 7,066 to $7,747 \mathrm{mg} / 100 \mathrm{~g}$. These values are higher than those $(5,971-6,499 \mathrm{mg} / 100 \mathrm{~g})$ reported by Kim and Lee [1]. The total amino acid content was highest in T5 and lowest in T1. Such differences in the levels of total amino acids are considered to be attributable to differences in crude protein content, as shown in Table 2. Similar to mineral contents, information on total and individual amino acids, including essential amino acids, is rare for home-grown forages in Korea. This is of particular concern in the dairy sector, in which the concept of rumen degradable and rumen undegradable protein is adopted to formulate diets for high-producing dairy cows in Korea. Thus, considerable information on amino acid profiles is required for domestically produced forages. In this regard, our laboratory has previously reported on the amino acid profiles of corn silage [30] and sorghum $\times$ sudangrass hybrids [31].

\section{Free sugar contents}

The free sugar contents in whole-crop barley were in the order sucrose $>$ glucose $>$ fructose (Table 5). In terms of individual sugar contents, T1 had the highest content and T5 had the lowest when expressed per $100 \mathrm{~g}$ dry matter basis $(p<0.05)$. Although the free sugar content is high at the early stage of grain maturation, it decreases as the grain matures [32]. The highest free sugar content of T5 appeared to be related to the stage of maturity (harvest of the milk stage). Generally, the free sugar content of forage crops is a very important ingredient because it affects silage fermentation $[25,28]$. In particular, a higher free sugar content is associated with a decreased rate of butyric acid and ammonia-N production and increased lactic acid yield, through enhancement of the rate of mi- 
Table 4. Effects of seeding dates on the amino acid profile of whole-crop barley cultivated in a paddy field (mg/100 $\mathrm{g}$ dry matter basis unless otherwise stated)

\begin{tabular}{|c|c|c|c|c|c|}
\hline \multirow{2}{*}{ Items } & \multicolumn{5}{|c|}{ Treatments ${ }^{1)}$} \\
\hline & T1 & T2 & T3 & T4 & T5 \\
\hline Threonine & $268 \pm 14^{\text {ns }}$ & $260 \pm 10$ & $269 \pm 6$ & $272 \pm 2$ & $262 \pm 8$ \\
\hline Valine & $460 \pm 26^{\text {ns }}$ & $458 \pm 12$ & $482 \pm 4$ & $504 \pm 43$ & $518 \pm 15$ \\
\hline Methionine & $34 \pm 1^{\text {ns }}$ & $33 \pm 1$ & $35 \pm 3$ & $33 \pm 3$ & $39 \pm 3$ \\
\hline Isoleucine & $298 \pm 15^{\mathrm{ns}}$ & $291 \pm 9$ & $312 \pm 5$ & $310 \pm 8$ & $304 \pm 11$ \\
\hline Leucine & $504 \pm 25^{\text {ns }}$ & $490 \pm 10$ & $511 \pm 3$ & $508 \pm 3$ & $482 \pm 4$ \\
\hline Phenylalanine & $450 \pm 6^{\text {ns }}$ & $478 \pm 12$ & $490 \pm 7$ & $489 \pm 14$ & $476 \pm 30$ \\
\hline Histidine & $218 \pm 2^{\text {ns }}$ & $226 \pm 6$ & $238 \pm 2$ & $248 \pm 3$ & $254 \pm 30$ \\
\hline Lysine & $406 \pm 26^{\text {ns }}$ & $410 \pm 11$ & $428 \pm 7$ & $428 \pm 8$ & $397 \pm 12$ \\
\hline Arginine & $305 \pm 11^{\text {ns }}$ & $307 \pm 5$ & $332 \pm 4$ & $326 \pm 11$ & $331 \pm 20$ \\
\hline Sum of EAA & $2,943 \pm 127^{\mathrm{ns}}$ & $2,953 \pm 31$ & $3,097 \pm 23$ & $3,118 \pm 84$ & $3,063 \pm 39$ \\
\hline Serine & $270 \pm 9^{\text {ns }}$ & $278 \pm 7$ & $292 \pm 4$ & $296 \pm 24$ & $285 \pm 26$ \\
\hline Glutamic acid & $1,086 \pm 27^{\text {ns }}$ & $1,055 \pm 53$ & $1,065 \pm 55$ & $1,117 \pm 34$ & $1,076 \pm 21$ \\
\hline Proline & $1,035 \pm 4^{\mathrm{ns}}$ & $924 \pm 98$ & $1,138 \pm 29$ & $1,148 \pm 7$ & $1,140 \pm 41$ \\
\hline Glycine & $299 \pm 10^{\text {ns }}$ & $293 \pm 8$ & $306 \pm 6$ & $304 \pm 4$ & $289 \pm 11$ \\
\hline Alanine & $339 \pm 31^{\text {ns }}$ & $406 \pm 16$ & $425 \pm 6$ & $423 \pm 6$ & $408 \pm 5$ \\
\hline Tyrosine & $97 \pm 7^{\text {ns }}$ & $94 \pm 2$ & $102 \pm 1$ & $101 \pm 1$ & $107 \pm 5$ \\
\hline Aspartic acid & $997 \pm 34^{\text {ns }}$ & $1,115 \pm 48$ & $1,177 \pm 6$ & $1,171 \pm 61$ & $1,381 \pm 24$ \\
\hline Sum of NEAA & $4,123 \pm 101^{\mathrm{c}}$ & $4,315 \pm 41^{b}$ & $4,505 \pm 13^{\mathrm{a}}$ & $4,560 \pm 52^{\mathrm{a}}$ & $4,686 \pm 96^{a}$ \\
\hline Total amino acids & $7,066 \pm 26^{b}$ & $7,268 \pm 11^{b}$ & $7,602 \pm 27^{\mathrm{a}}$ & $7,678 \pm 136^{a}$ & $7,747 \pm 135^{\mathrm{a}}$ \\
\hline
\end{tabular}

Data are expressed as means \pm SD.

Means in a row with different superscripts are significantly different $(p<0.05)$.

${ }^{11} \mathrm{~T} 1, \mathrm{~T} 2, \mathrm{~T} 3, \mathrm{~T} 4$, and T5 represent the different seeding dates: October 19, October 26, November 2, November 9, and November 16, respectively.

ns, not significant; EAA, essential amino acids; NEAA, non-essential amino acids.

Table 5. Effects of seeding dates on the free sugar contents of whole-crop barley cultivated in a paddy field (mg/100 $\mathrm{g}$ dry matter unless otherwise stated)

\begin{tabular}{|c|c|c|c|c|c|}
\hline \multirow{2}{*}{ Items } & \multicolumn{5}{|c|}{ Treatments $^{11}$} \\
\hline & T1 & T2 & T3 & T4 & T5 \\
\hline Fructose & $913 \pm 77^{a}$ & $907 \pm 64^{a}$ & $572 \pm 25^{b}$ & $284 \pm 11^{c}$ & $209 \pm 15^{c}$ \\
\hline Glucose & $1,498 \pm 62^{\mathrm{a}}$ & $1,488 \pm 72^{a}$ & $1,371 \pm 19^{b}$ & $1,208 \pm 24^{c}$ & $1,262 \pm 45^{c}$ \\
\hline Sucrose & $1,878 \pm 66^{a}$ & $1,713 \pm 44^{b}$ & $1,685 \pm 59^{b}$ & $1,508 \pm 67^{c}$ & $1,304 \pm 21^{d}$ \\
\hline Total & $4,289 \pm 202^{a}$ & $4,108 \pm 179^{a}$ & $3,628 \pm 59^{b}$ & $3,000 \pm 53^{c}$ & $2,775 \pm 42^{\mathrm{c}}$ \\
\hline
\end{tabular}

Data are expressed as means $\pm \mathrm{SD}$.

Means in a row with different superscripts are significantly different $(p<0.05)$.

${ }^{1} \mathrm{~T} 1, \mathrm{~T} 2, \mathrm{~T} 3, \mathrm{~T} 4$, and T5 represent the different seeding dates: October 19, October 26, November 2, November 9, and November 16, respectively.

crobial fermentation. It has also reported that a high sugar content maintains $\mathrm{pH}$ at a low level, thereby promoting the rapid stabilization of silage [33].

\section{Competing interests}

No potential conflict of interest relevant to this article was reported.

\section{Funding sources}

Not applicable.

\section{Acknowledgements}

Not applicable.

\section{Availability of data and material}

Upon reasonable request, the datasets of this study can be available from the corresponding author.

Authors' contributions

Conceptualization: Lee SM. 
Data curation: Lee SM.

Formal analysis: Lee SM.

Methodology: Lee SM.

Investigation: Lee SM, Kim EJ.

Writing - original draft: Lee SM, Kim EJ.

Writing - review \& editing: Lee SM, Kim EJ.

\section{Ethics approval and consent to participate}

This article does not require IRB/IACUC approval because there are no human and animal participants.

\section{ORCID}

Sang Moo Lee

https://orcid.org/0000-0003-2510-2591

Eun Joong Kim

https://orcid.org/0000-0002-5962-6994

\section{References}

1. Lee SM, Kim EJ. Study on nutritive values of whole crop barley varieties grown in a paddy field. J Korean Soc Grassl Forage Sci. 2013;33:30-8.

2. Kim MJ, Choi KJ, Kim JG, Seo S, Yoon SH, Lim YC, et al. Effect of varieties and seeding date on over winter and dry matter yield of Italian ryegrass in paddy field. J Korean Soc Grassl Forage Sci. 2009;29:321-8.

3. Park TI, Han OK, Seo JH, Choi JS, Park KH, Kim JG. New barley cultivars with improved morphological characteristics for whole crop forage in Korea. J Korean Soc Grassl Forage Sci. 2008;28:193-202.

4. Yun SK, Park TI, Seo JH, Kim KH, Song TH, Park KH, et al. Effect of harvest time and cultivars on forage yield and quality of whole crop barley. J Korean Grassl Forage Sci. 2009;29:121-8.

5. Choi SH, Hwangbo S, Kim SW, Kim WH, Jo IH. Effects of feeding level of concentrate on the digestible nutrient intake, using efficiency of nutrients and nitrogen retention of Korean black goat fed whole crop barley silage.J Korean Grassl Forage Sci. 2010;30:59-66.

6. Seo S, Kim WH, Kim JG, Choi GJ, Kim KY, Cho WM, et al. Effect of whole crop barley silage feeding on the growth performance, feed requirement and meat quality of Hanwoo steers.J Korean Grassl Forage Sci. 2010;30:257-66.

7. Kim HY, Chu GM, Kim SC, Ha JH, Kim JH, Lee SD, et al. The nutritive value of grains from barley cultivars (Wooho, Youngyang, Yuyeon). J Agric Life Sci. 2012;46:69-78.

8. Kim WH, Seo S, Chung ES, Shin DE, Park TI, Koh JM, et al. Selection of promising barley cultivar for silage. 1. Growth characteristics and fresh matter yield. J Korean Grassl Sci. 2002;22:201-8.

9. Kim WH, Seo S, Yoon SH, Kim KY, Cho YM, Park TI, et al. Selection of promising barley cultivar for silage 2 . Nutrient value and total digestible nutrient yield. J Korean Grassl Sci. 2003;23:283-8.

10. Kim WH, Seo S, Lim YC, Shine JS, Sung BR, Ji HC, et al. Selection of promising barley cultivar for silage at paddy field of Honam region. J Korean Grassl Forage Sci. 2007;27:161-6.

11. Song TH, Han OK, Yun SK, Park TI, Seo JH, Kim KH, et al. Changes in quantity and quality of winter cereal crops for forage at different growing stages. J Korean Grassl Forage Sci. 2009;29:129-36.

12. Kim WH, Seo S, Shin JS, Lim YC, Kim KY, Jung MW, et al. Effect of seeding date and rate on the agronomic characteristics and yield of forage barley. J Korean Grassl Sci. 2006;26:155-8.

13. Choi JS, Kim JG, Baek SB, Park KH, Kwon YU, Park HH, et al. A ruminant-palatable hood type barley cultivar "Yuyeon" or whole-crop-forage use. Korean J Breed Sci. 2007;39:242-3.

14. Lee SM. Effects of seeding dates on yield and feed value of Italian ryegrass in paddy field cultivation.J Korean Soc Grassl Forage Sci. 2013;33:185-92.

15. AOAC. Official methods of analysis. 16th ed. Washington, DC: Association of Analytical Chemist; 1995.

16. AOAC. Official methods of analysis Proximate analysis and calculations acid detergent fiber (ADF) - item 1. Reference data: Method 973.18 (A-D). 17th ed. Gaithersburg, MD: Association of Analytical Communities; 2006.

17. Goering HK, Van Soest PJ. Forage fiber analysis, agriculture handbook no. 379. Washington, DC: U.S. Department of Agriculture; 1970.

18. Moore JE, Undersander DJ. Relative forage quality: An alternative to relative feed value and quality index. In: Proceedings 13th Annual Florida Ruminant Nutrition Symposium; 2002; Gainesville, FL. p.16-32.

19. Wilson AM, Work TM, Bushway AA, Bushway RJ. HPLC determination of fructose, glucose, and sucrose in potatoes. $\mathrm{J}$ Food Sci. 1981;46:300-1.

20. SAS Institute Inc. What's new in $\mathrm{SAS}^{\circledR}$ 9.3. Cary, NC: SAS Institute Inc.; 2012.

21. Suh HS. Comparison of several agronomic characteristics as affected by seeding dates. Korean J Crop Sci. 1981;26:298303.

22. Kim MJ, Choi GJ, Yook WB, Lim YC, Yoon SH, Kim JG, et al. Effects of seeding method on the winter survival, dry matter yield and nutrient value of Italian ryegrass in paddy field.J Korean Grassl Forage Sci. 2007;27:269-74.

23. Hwang KJ, Ko SB, Park HS, Park NG, Ko MS, Jeong HY, et al. Effects of the cutting time on forage yield and quality in Italian ryegrass (Lolium multiflorum Lam.) and oat (Avena 
sativa L.) seeded singly or in combination. J Korean Grassl Forage Sci. 2008;28:295-300.

24. Seo S, Kim MJ, Kim WH, Lee SH, Jung MW, Kim KY, et al. Optimum harvest stage of Italian ryegrass 'Kowinearly' according to one and two harvests during spring season. J Korean Soc Grassl Forage Sci. 2013;33:15-20.

25. Lee SM. Effects of mixed application of chemical fertilizer and liquid swine manure on agronomic characteristics, yield and feed value of corn hybrid for silage in paddy field cultivation. J Korean Soc Grassl Forage Sci. 2012;32:369-78.

26. Reid RL, Post AJ, Jung GA. Mineral composition of forages. Bull W Va Agric Exp Stn. 1970;589T.

27. Kim MC. Effects of nitrogen and potassium application on pasture of Cheju volcanic soil. I. Dry matter yield and mineral concentration (N, P, K, Ca, Mg, Na) of orchardgrass. Korean J Anim Sci. 1991;33:683-91.

28. Lee SM, Lee JH. Effects of seeding dates and growth periods on the growth characteristics, dry matter yield and feed value of corn for silage in paddy field. J Anim Sci Tech.
2010;52:441-8.

29. Harnly JM, Wolf WR. Atomic spectrometry for inorganic elements in foods. In: Charalambous G, editor. Analysis of foods and beverages: modern techniques. London: Academic Press; 1984. p.452-81.

30. Kim WS, Hwang JH, Lee JH, Kim EJ, Jeon BT, Moon SH, et al. A comparative study on the growth characteristics and nutritional components of corn hybrids for silage at paddy field cultivation.J Korean Grassl Forage Sci. 2012;32:15-28.

31. Jeon BT, Moon SH, Lee SM. A comparative studies on the growth characteristics and feed components of sorghum $\times$ sudangrass hybrids at paddy field cultivation. J Korean Grassl Forage Sci. 2012;32:29-38.

32. Chatterton NJ, Watts KA, Jensen KB, Harrison PA, Horton WH. Nonstructural carbohydrates in oat forage. J Nutr. 2006;136 Suppl 7:2111S-3S.

33. Davies DR, Merry RJ, Williams AP, Bakewell EL, Leemans DK, Tweed JK. Proteolysis during ensilage of forages varying in soluble sugar content.J Dairy Sci. 1998;81:444-53. 